\title{
THE TOXICOLOGICAL EFFECT OF PARAQUAT POST EMERGENCE HERBICIDE ON GROWTH CHARACTERISTICS OF COWPEA (Vigna unguiculata (L.) Walp)
}

\author{
* ${ }^{1}$ FAYINMINNU, O. O. AND ${ }^{2}$ ADESIYAN, S.O. \\ ${ }^{1}$ Department of Crop Production, College of Agricultural Sciences, Olabisi Onabanjo \\ University, P.M.B 0012, Ayetoro, Ogun State, Nigeria. \\ ${ }^{2}$ Department of Crop Protection and Environmental Biology, Faculty of Agriculture \\ and Forestry, University of Ibadan, Ibadan, Oyo State, Nigeria.
}

\section{Corresponding author's Email: olorijkb2008@yahoo.co.uk}

\begin{abstract}
The study was conducted to examine the effect of paraquat herbicide on growth characteristics of cowpea. The paraquat herbicide was applied at two rates; 0.50 and $1.00 \mathrm{~kg}$ ai/ha. Information was obtained on the vegetative growth parameters of cowpea which included plant height, number of leaves, leaf area, phytotoxicity and weed control effectiveness of the herbicide. The results showed that there were significant differences $(P<$ $0.05)$ in vegetative growth in cowpea plants when paraquat was used as post emergence herbicide for weed control. There was good growth and adequate weed control achieved by all herbicide treatments evaluated until 9 weeks after planting (WAP) before decline set in. However, cowpea plant heights were significantly higher $(P<0.05)$ in plots treated with paraquat at $1.00 \mathrm{~kg}$ ai/ha. Highest number of leaves was recorded during growth at $4-6$ WAP with paraquat at $1.00 \mathrm{~kg}$ ai/ha. The leaf area also showed significant difference $(P<0.05)$ in plants treated with handweeded and paraquat herbicide at 0.50 and $1.00 \mathrm{~kg}$ ai/ha. However, cowpea vegetative growth performance in herbicide treatments compared favourably with handweeded control plots and better than the unweeded control. Phytotoxicity symptoms to cowpea plants was high in paraquat treated plots at the rate of $1.00 \mathrm{~kg}$ ai/ha than at $0.50 \mathrm{~kg}$ ai/ha at 4 - $6 \mathrm{WAP}$. The highest plant height and leaf area were obtained from handweeded control plots while the unweeded plots gave the poorest growth parameters.
\end{abstract}

Key words: Weed Management, Herbicide Treatment, Sole cowpea cropping

\section{INTRODUCTION}

Cowpea is an important leguminous crop and a major food crop of millions of people in developing countries of the world. Cowpea provides cheap and nutritious food for relatively poor urban communities (Quin,1997). Cowpea also has potential for multiple contributions not only to household food security, but also as a cash crop (grain and fodder). It also brings nitrogen into farming system through nitrogen fixation (Tarawali et al., 2000). Nigeria accounts for $70 \%$ of world's cowpea production, the bulk which is grown in the drier regions of Northern Nigeria (I.ITA, 1998: Alghali 1991). Total land area under cowpea production is 12.5 million/ha (Singh and Emechebe, 1997) and the world production was estimated at 3 319375 million metric tonne (FAO, 2000). Nigeria and Niger are ahead with a production of 2099000 and 641000 metric tonnes respectively, in 1999 (FAO, 2000).

There are many constants to cowpea production in Nigeria which include attack by insect pests, indentation by disease pathogens, soil infertility; poor weather conditions and weed infestation particularly parasitic weeds like Striga gesneroides and Alectra vogelli which contributed to low yield (Ofuya and Credland, 1995; Ayeni et al., 1996; Quin, 1997; Alonge and Lagoke, 2002). The first 3-4 weeks of cowpea growth are critical period of 
weed competition (Bhan et al., 1982; Akinyemiju and Echendu, 1987). Cowpeas are highly susceptible to pernicious weeds such as itchgrass, Rottboella cochichinensis (Louis Clayton); milk weed, Euphorbia heterophylla (Desv); and Calopogonium mucunoides (Akobundu, 1987).

Quin (1997) reported that Nigerian farmers carry out weed control with hoe at 3 and 5 weeks after planting. This is however associated with drudgery and high cost of labour (Olunuga, 1997). Studies have shown that recommended herbicides had not totally solved the problems of weeds on farmers' fields due to inadequate selectivity of herbicides in action. Galex failed to control some weed species in cowpea fields which has reduced its value for use in cowpea (Akobundu, 1979; 1982). Akobundu (1987) reported further that cowpea varieties differ in a lot of characteristics amongst which is response to herbicide treatments. Fadayomi (1991) noted that there was adoption of chemical weed control option to a large extent. Cowpea performance also depends much on spraying with appropriate agrochemicals. Paraquat is one of the most widely used herbicides to control broad-leaved and grasses weeds as post emergence herbicide in the tropics (Summers 1980). Summers (1980) gave the symptoms of paraquat injury on weeds as rapid, wilting, scorching and desiccation of the treated foliage. Fadayomi (1979) found that early post emergence application of paraquat in sugar cane farm with other combinations of herbicides satisfactorily controlled weeds without any crop injury. The objective of this paper is to present the toxicological effects of paraquat (a post emergence herbicide) on the growth characteristics of cowpea (Vigna unguiculata (L). Walp).

\section{MATERIALS AND METHODS}

The trial experiment was conducted at the Crop Garden of Department of Crop Protection and Environmental Biology, Faculty of Agriculture and Forestry, University of Ibadan, Ibadan. Materials used for the experiment were Ife brown cowpea variety and paraquat herbicide. Ife brown seeds were obtained from the germplasm of Department of Crop Protection and Environmental Biology. Paraquat application rates were 0.50 and $1.00 \mathrm{~kg}$ ai/ha. These were applied as post emergence. with hand weeded and unweeded as controls.

The treatments were randomly assigned to plastic pots (each was $25 \mathrm{~cm}$ in diameter) filled with unsterilized clay loamy soil and the treatments were replicated six times in a Complete Randomised Design (CRD). Two seeds of cowpea were planted in a hole which was later thinned to one plant after emergence. The herbicides were applied by using a Veltox pressure hand sprayer of 2.5 litre volume. Routine cultural practices were carried out which included daily watering of pots, handweeding and paraquat application were carried out at 3 and 5 WAP. Cypermethrin was used to control insect pests at $0.20 \mathrm{~kg}$ ai/ha.

Treatment effects were assessed on plant height and number of leaves which were taken 3, 6 and 9 weeks after planting (WAP). The plant height was measured with a meter rule while the number of leaves was merely counted physically. The leaf area was estimated with leaf area metre. Phytotoxicity to the crop was rated using the criteria developed by Clay and Davison (1978), on a scale of $0-10$ where " 0 " represents no injury and ' 10 ' represents dead plants. The data collected were analyzed using the analysis of variance (ANOVA) and means compared using Duncan's Multiple Range Test (DMRT) at 5\% level of probability. Weed control was visually rated on a scale of $0-100 \%$ where " $0 \%$ represents no weed control and " $100 \%$ " represents excellent weed control.

\section{RESULTS AND DISCUSSION}

The fallow weed species in the experimental pots were Aspergillia africana, Tridax procumbens L. Euphorbia heterophylla L. Agerantum conyzoides L.Cyanodon dactylon. These weeds were broad leaf and annual weeds except Cyanodon dactylon, a grass. 
Significant differences $(\mathrm{P}<0.05)$ indicated that paraquat has effect on vegetative growth of cowpea. Table 1 showed the effect of paraquat herbicide treatments on cowpea growth. The plots treated with paraquat herbicide at $1.00 \mathrm{~kg}$ ai/ha application rate gave the highest plant height which was significantly different $(\mathrm{P}<0.05)$ from the plots treated with paraquat at the application rate of $0.50 \mathrm{~kg}$ ai/ha and unweeded plots. Number of leaves produced in the plots treated with paraquat herbicide at the rate of $1.00 \mathrm{~kg}$ ai/ha was the highest and this was significantly different $(\mathrm{P}<0.05)$ from $0.50 \mathrm{~kg}$ ai $/$ ha application rate of paraquat herbicide. However, there was no significant difference $(\mathrm{P}<0.05)$ between the handweeded and paraquat herbicide treatment at $0.50 \mathrm{~kg}$ ai/ha application rate. Leaf Area showed significant differences $(\mathrm{P}<0.05)$ amongst the treatments. The handweeded cowpea plot recorded the highest leaf area which differed significantly $(\mathrm{P}<0.05)$ from paraquat herbicide treatments at 0.50 and $1.00 \mathrm{~kg}$ ai/ha and unweeded treatments. Cowpea growth parameters from the plots with paraquat herbicide treatment at $1.00 \mathrm{~kg}$ ai/ha favourably compared with growth parameters realized from the hand weeded control plots while the unweeded plots showed the poorest growth.

Table 2 showed the phytotoxicity of the paraquat herbicide treatments to cowpea and the weed control effectiveness at 3, 6 and 9 weeks after planting (WAP). Phytotoxicity symptoms were higher at $3 \mathrm{WAP}$ for paraquat at $1.00 \mathrm{~kg}$ ai $/$ ha, although there was a gradual decline as time progressed. Paraquat at the rate of $0.50 \mathrm{~kg}$ ai/ha produced low phytotoxic symptoms to cowpea. The rate of decline of phytotoxicity over time was rapid. Weed control in all the paraquat treated plots was good and adequate up to 9 WAP as post emergence herbicide. Significant differences $(\mathrm{P}<0.05)$ were recorded amongst all the treatments. Plots treated with handweeded recorded excellent weed control over other treatments. Plots treated with paraquat herbicide at $1.00 \mathrm{~kg}$ ai $/$ ha application rate showed high weed control than the plots treated with paraquat herbicide at $0.50 \mathrm{~kg}$ ai $/ \mathrm{ha}$ application rate while the unweeded plots recorded poorest weed control.

The results showed good vegetative growth of plant height, number of leaves and leaf area produced by all the treated plots. Paraquat herbicide treatment at $1.00 \mathrm{~kg}$ ai/ha showed higher cowpea growth than the paraquat herbicide treatment at $0.50 \mathrm{~kg}$ ai $/ \mathrm{ha}$ application rate. This showed that the paraquat herbicide at $1.00 \mathrm{~kg}$ ai/ha application rate was able to control the weeds of cowpea effectively which also resulted into positively influenced vegetative growth of cowpea. However, the handweeded plots showed highest cowpea growth and weed control amongst all the treatments. This was really reflected in higher crop vigour and leaf area by the weeded plots when compared with the unweeded plots. Weeds are known to compete with corps for space, light, water and nutrient, (Fadayomi 1979) and Ayeni et al., (1984) which had all been noted to affect growth of cowpea crop in unweeded plots.

The results of this good growth parameter recorded in the plots treated with handweeded, paraquat herbicide at $1.00 \mathrm{~kg}$ ai $/$ ha and $0.50 \mathrm{~kg}$ ai $/$ ha application rates confirmed the work of Singh et al., (1998) that earlier weeding at 3 and 5 WAP is enough for cowpea because the critical period of weed competition in cowpea is the first 3 - 4 WAP. According to Akinyemiju and Echendu (1987), a weed-free period for the first 6 WAP was recommended in cowpea production. Paraquat herbicide treated plots also produced high leaf area which suggests that there was no crop injury at the applied rates of 0.50 and $1.00 \mathrm{~kg}$ ai/ha and also there was reduction in weeds at the growing period. The plants with high leaf area intercepted more incidents light earlier in the growing season (Westgate et al., 1997).

The results of the present study showed that paraquat at $1.00 \mathrm{~kg}$ ai/ha gave a good control of cowpea weeds throughout the trial as confirmed by Moody (1973). Results from the trials also indicated that paraquat, a post early emergence herbicide at $1.00 \mathrm{~kg}$ ai $/ \mathrm{ha}$ is more effective in controlling cowpea weeds without any crop injury (Fadayomi 1979). 


\section{CONCLUSION AND RECOMMENDATIONS}

Paraquat as a post emergence herbicide is a good weed control especially when applied at $1.00 \mathrm{~kg}$ ai/ha without any crop injury. It was able to control the weeds in cowpea plots at 4 $6 \mathrm{WAP}$ thereby making it critical weed - free. It is recommended that, cowpea be produced at optimally level with adequate use of paraquat at the rate of $1.00 \mathrm{kgai} / \mathrm{ha}$ in order to control the weeds (Aspergillia africana, Tridax procumbens L. Euphorbia heterophylla L. Agerantum conyzoides L.Cyanodon dactylon ) without affecting the vegetative growth characteristics of cowpea.

Table 1: Toxicological Effect of Paraquat as Post Emergence Herbicide on growth of cowpea.

\begin{tabular}{lccc}
\hline Treatments $\quad$ Rates & $\begin{array}{c}\text { Plant } \\
\text { Height } \\
(\mathbf{c m})\end{array}$ & $\begin{array}{c}\text { Number } \\
\text { of } \\
\text { Leaves }\end{array}$ & $\begin{array}{c}\text { Leaf } \\
\text { Area }(\mathbf{c m})\end{array}$ \\
\hline Paraquat $\quad 1.00 \mathrm{~kg} \mathrm{ai} / \mathrm{ha}$ & $20.70^{\mathrm{a}}$ & $14.00^{\mathrm{a}}$ & $25.73^{\mathrm{ab}}$ \\
Paraquat $\quad 0.50 \mathrm{~kg} \mathrm{ai} / \mathrm{ha}$ & $18.70^{\mathrm{a}}$ & $8.25^{\mathrm{ab}}$ & $23.62^{\mathrm{c}}$ \\
Handweeded $\quad-$ & $20.50^{\mathrm{a}}$ & $10.50^{\mathrm{ab}}$ & $34.89^{\mathrm{a}}$ \\
Unweeded & $14.47^{\mathrm{c}}$ & $2.50^{\mathrm{b}}$ & $9.41^{\mathrm{d}}$ \\
Treatment Mean & 18.59 & 8.81 & 23.41 \\
S.E $\quad$ & 1.25 & 2.09 & 4.57 \\
\hline
\end{tabular}

Means followed by the same letter within a column are not significantly different at $(\mathrm{P}<0.05)$ level of probability using DMRT.

Table 2: Phytotoxicity to cowpea and Weed Control Effectiveness of Paraquat as Post Emergence Herbicide.

\begin{tabular}{|c|c|c|c|c|c|c|c|}
\hline \multirow[t]{2}{*}{ Treatments } & \multirow[t]{2}{*}{ Rates } & \multicolumn{3}{|c|}{ Phytotoxicity } & \multicolumn{3}{|c|}{ Weed Control \% } \\
\hline & & Weeks & After & Planting & Weeks & After & Planting \\
\hline & & 3 & 6 & 9 & 3 & 6 & 9 \\
\hline Paraquat 1.0 & 0kg ai/ha & $5.00^{\mathrm{a}}$ & $5.00^{\mathrm{a}}$ & $3.50^{\mathrm{a}}$ & $60^{b}$ & $60^{\mathrm{b}}$ & $50^{\mathrm{b}}$ \\
\hline Paraquat 0.5 & $50 \mathrm{~kg}$ ai/ha & $3.50^{\mathrm{b}}$ & $3.00^{\mathrm{b}}$ & $1.50^{\mathrm{b}}$ & $45^{\mathrm{c}}$ & $45^{\mathrm{c}}$ & $35^{\mathrm{c}}$ \\
\hline Hand weeded & - & $0^{\mathrm{c}}$ & $0^{\mathrm{c}}$ & $0^{\mathrm{c}}$ & $100^{\mathrm{a}}$ & $100^{\mathrm{a}}$ & $90^{\mathrm{a}}$ \\
\hline Unweeded & - & $0^{\mathrm{c}}$ & $0^{\mathrm{c}}$ & $0^{\mathrm{c}}$ & $0^{\mathrm{d}}$ & $0^{\mathrm{d}}$ & $0^{\mathrm{d}}$ \\
\hline Treatment $\mathrm{M} \epsilon$ & & 2.13 & 2.00 & 1.25 & 51.25 & 51.25 & 43.75 \\
\hline S.E \pm & & 1.10 & 1.49 & 0.53 & 17.89 & 17.89 & 16.44 \\
\hline
\end{tabular}

Means followed by the same letter within a column are not significantly different at $(\mathrm{P}<0.05)$ level of probability using DMRT.

1. Phytotoxicity is rated on a scale of 0-10 where $0 `$ means no injury and 10 ` means complete mortality.

2. Weed Control is rated on a scale of 0-100 where ` 0 ' means no weed control and $100 `$ means excellent weed control.

\section{REFERENCES}

Akinyemiju, O. A. and Echendu, T.N.C. (1987): Influence of different tillage methods and pre-emergence herbicides on weed control in cowpea (Vigna unguiculata (L.) Walp). Crop Protection 6:289 - 294.

Akobundu. I. O. (1979: An evaluation of selected cowpea cultivars for herbicides tolerance.

Proceedings of the 9th Annual Conference of the Weed Science Society of Nigeria held at I.I.T.A., Ibadan, Pp 69 - 74. 
Akobundu, I. O. (1982): "Weed control in cowpea (Vigna unguiculata) in humid tropics" Weed Science, 30:331-334.

Akobundu, I. O. (1987): Weed Science in the tropics Principles and Practices. U.S.A, John Willey and sons Publication 522pp.

Alghali, A. M. (1991): "The effect of plant spacings on cowpea (Vigna unguiculata (L). Walp), insect pest and yields in two sites in Nigeria. Inter-science and its Application 12:5 - 6, 707 - 711: In Proceedings of the AAIS and the Entomological Society Zambia Annual General and Scientific meetings, Lusaka, Zambia. 4 - 8 Dec., 1989.

Alonge, S. O. and Lagoke, S.T.O (2002): Parasitism of cowpea varieties by Alectra vogelli and Striga gesneriodes" Nigeria Journal of Weed Science. 15:39-51

Ayeni, A. O., Duke W. B., and Akobundu I. O. (1984): "Weed interference in maize, cowpea and maize cowpea intercrop in a sub humid tropical, environment: Influence of cropping season. Weed Research 24:265 - 271.

Ayeni, A. O., Ikuenobe C. E., and Majek, B. A. (1996): Effect of Imasaquine-based herbicide mixtures on cowpea, soy bean and selected tropical weeds. Nigerian Journal of Weed Science 9:49 - 56.

Bhan, V. M., Balyan, R. S., and Singh, S. P. (1982): Influence of time of weed removal and weed species on grain yield of cowpea. Indian Journal of Agronomy 27 (3) 95:267271.

Clay, D. V. and Davison, J. G. (1978): "An evaluation of sand culture techniques for studying the tolerance of fruit crop to soil-acting herbicides." Weed Research, Oxford, 18:139-147.

Fadayomi, O. (1979): "Weed competition and cost effectiveness of different weed control alternative in cowpea (Vigna unguiculata (L.) Walp)." Proceedings of the 9th Annual Conference of the Weed Science Society of Nigeria - Pp 43 - 48.

Fadayomi, O. (1991): An evaluation of several herbicides combinations for weed control in Sugarcane. Proceedings XVIII. Congress of ISSCT Pp $257-265$.

F.A.O. (2000): FAOSTAT Database. http://apps.fao.org Food and Agriculture Organisation of the United Nations, Rome Italy. Accessed June 2000.

I.I.T.A (1998): International Institute of Tropical Agriculture. Dry Season cowpea. 1993, Annual Report IITA Ibadan, Nigeria.

Mc Cary, M. T. (1983): "Economic thresholds of annual grasses in agronomic crops" Ph. D Dissertation, North California State University Library, Raleigh. Pp 23 - 25.

Moody, K. (1973): Weed control in cowpea. Proceedings of the Weed Science Society of Nigeria. Vol. 13:9 -13

Ofuya, T. I. and Credland, P. F. (1995): "Differences in the susceptibility of seeds of selected varieties of cowpea to Bruchidius atrolineatus (Coleoptera: Bruchidae)". Bulletin of Entomological Research 85:259 - 265.

Olunuga, B. A. (1997): "Effective weed management under a deregulated economy. Agricultural Extension perspective: Nigerian Journal of Weed Science Vol. 10:77 81.

Quin, F. M. (1997): "Introduction: Advances in Cowpea Research" co-publications of IITA and JIRCAS on cowpea. 1998 edition Pp 9 -25

Singh, B.B., Emechebe, A.M.(1997): Advances in research on cowpea Striga and Alectra. Pp 215 - 223 in Advances in cowpea research, edited by Singh, B.B., Mohan Raj, D.R., Danshiell, K.E. and Jackai, L.E.N. Co - publication of IITA and JIRCAS, IITA, Ibadan, Nigeria.

Singh, B. B., Chambis, O. L., and Sharma, B. (1998): Preface to advance in cowpea Research Co-publication of I.I.T.A and JIRCA on cowpea 1998 edition - Pp 9-25. 
Summers, L. A. (1980): The Bipyridium Herbicides Academic Press, New York. 421 pp. Tarawali, S. A., Larhi, S. Fernandez-Rivera, and Bationo, A. (2000): The role of livestock in the maintainance and improvement of soil fertility. In:" Sustaining soil fertility in West Africa" SSSA Special Publication No. 58. Soil Society of America and American Society of Agronomy, Madison, USA. Pp 281 - 203

Westgate, M.E., Forcella, F., Reicosky, D. C. and Somsen, J. (1997)Rapid canopy closure for maize production in the northern US corn belt; Radiation - use efficiency and grain yield. Field Crops Research 49: 249 - 258. 